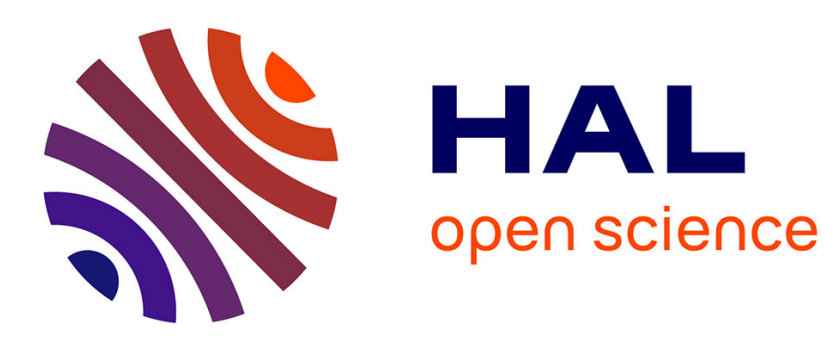

\title{
An exploration of institutional constraints on developing end-of-life product recovery capabilities Joe Miemczyk
}

\section{To cite this version:}

Joe Miemczyk. An exploration of institutional constraints on developing end-of-life product recovery capabilities. International Journal of Production Economics, 2008, 115 (2), pp.272-282. 10.1016/j.ijpe.2008.04.013 . hal-00765366

\section{HAL Id: hal-00765366 https://hal.science/hal-00765366}

Submitted on 19 Feb 2015

HAL is a multi-disciplinary open access archive for the deposit and dissemination of scientific research documents, whether they are published or not. The documents may come from teaching and research institutions in France or abroad, or from public or private research centers.
L'archive ouverte pluridisciplinaire HAL, est destinée au dépôt et à la diffusion de documents scientifiques de niveau recherche, publiés ou non, émanant des établissements d'enseignement et de recherche français ou étrangers, des laboratoires publics ou privés. 


\title{
An exploration of Institutional constraints on developing end-of-life product recovery capabilities
}

\author{
Joe Miemczyk $k^{1}$ \\ Audencia Nantes School of Management
}

Abstract

The aim of this paper is to explore the implications of the institutional environment on end-oflife product recovery capabilities of manufacturing firms. The research takes an exploratory case study approach focusing on three producers and two firms in each of their recovery supply chains. The research finds that process capabilities for product recovery are linked to, but distinct from, capabilities for managing the institutional environment. Coercive pressure to adopt product recovery constrains the choices firms can make in terms of network structure and the development of capabilities. Where manufactures face uncertainty in their institutional environments and adopt a mimetic approach, the outcomes can be suboptimal.

Keywords: product recovery, institutionalism, constraints, end-of-life, capabilities

\footnotetext{
${ }^{1}$ J.Miemczyk, Audencia Nantes School of Management, 8, Rue de la Joneliere, 44312 Nantes, France, 0033240 374625, jmiemczyk@audencia.com
} 


\section{Introduction}

Current research in Western Europe shows that, if current trends continue, the volume of waste produced each year is expected to double by 2020 with commensurate effects on the natural environment ${ }^{2}$. While targets have been set by government to reduce this growth, levels of waste generation per capita per year are at a level of 550 kilograms, exceeding the current target by $83 \%$. This poses serious questions for society concerning how to balance economic activity and the resulting impacts on the ecosystems it relies upon. In response to this challenge, firms that manufacture products (producers) have started to consider what happens to products when their traditional responsibility ends.

This new and extended producer responsibility has led to the development of product recovery strategies - the aim of which is to reduce the impact of products on the natural environment at the end of their life (Guide Jr and Wassenhove 2002; Sharfman et al. 1997). Despite these developments by firms, legislation has progressed even faster, outpacing the 'proactive' initiatives of firms (CEC 2000, 2001; Charter 1992), setting into place regulations that specifically control the take-back and recycling of products to standards not yet reached by industry (Knemeyer et al. 2002; Spicer and Johnson 2004; Toffel 2003; Walther and Spengler 2005; White et al. 2003). The strategic implications of these new regulations is perceived by industry to be huge, for instance, European automakers estimate their costs to comply to be in the range of 500-800 Million Euros per manufacturer ${ }^{3}$. By expanding the scope of responsibility of firms to end-of-life products, the traditional operational scope also changes. This expanded scope of responsibility then stretches from manufacturing and use, to waste management, re-use, remanufacturing and recycling. Alongside this change in responsibilities for the environmentally sound disposition of end of life products, firms are considering how to integrate these changes into their existing operations (Guide $\mathrm{Jr}$ and Wassenhove 2003; Mayers and France 1999; McIntyre et al. 1998; Whiston 1995). However, simply utilizing existing structures for supply chain management and logistics and distribution to recovery end of life products is often not an option (Seitz and Peattie 2004). Although there are linkages between forward and reverse supply chains, they are often very separate entities. Furthermore, as firms are required to take on new responsibilities, it is unclear whether product manufacturers (often termed OEMs - Original Equipment Manufacturers) possess the

\footnotetext{
${ }^{2}$ European Environment Agency [2005] The European Environment: State and outlook, EEA Report, Copenhagen.

${ }^{3}$ Based on a Cost of 150-180 Euro per car sold (Thomson, J 2002 Europe's controversial 'End of Life Vehicle Directive, http://www.just-auto.com/article.aspx?id=86928\&lk=s, accessed 17 June 2002).
} 
necessary assets (physical, financial, skills and knowledge) to first, comply with new regulations, and second, ensure new responsibilities can be met without seriously harming competitiveness (Walley and Whitehead 1994; White et al. 2003). Given that product manufacturing firms often do not own the means to recover their own products at the end-oflife when discarded, firms have started to establish new relationships with firms that have acquired assets and developed skills for product recovery (Toffel 2003). Indeed, many firms have been engaged in these activities since the early days of industrial manufacturing, such as salvage operators, yet new regulations and social expectations mean that new forms of organising these activities are needed.

\section{Literature review}

\subsection{End of life product recovery networks}

Traditionally, manufacturers reduce the disposal impacts of their products through concepts and designs that consider these impacts before products are created (Dewhurst 1993). Spicer and Johnson (2004) explain that extended producer responsibility actually takes product stewardship further by suggesting manufacturers are responsible for the take-back, recycling and final disposal of the product. Pohlen and Farris (1992) examined this issue some years before in their discussion of reverse logistics and demonstrated that products usually do not return back through the same channel in which they were produced, but new reverse channels are needed to take-back, recycle and dispose of products at the end of their lives. Rogers and Tibben-Lemke (2001) state that in its broadest sense reverse logistics includes products sent back due to damage, seasonal inventory, restocking, salvage, recalls and excess inventory. They go on to explain that the specific activities associated with reverse logistics include reselling, remanufacturing, recycling, landfilling and repackaging. Yet with new legislative development, especially in Europe (and also Japan) the role of reverse logistics in product stewardship then is also concerned with the reduction of harmful effects of products at the disposal stage of a product's life (Carter and Ellram 1998).

Carter and Ellram (1998) develop a conceptual framework to show that successful reverse logistics programs are driven and constrained by a number of concepts. Thus regulations and customers are the key external drivers, while policy entrepreneurs, such as managers who support the program are a key internal driver. The success of a reverse logistics program is thought to be dependent on a number of other factors. These are described by Carter and Ellram (1998) as the quality of inputs, vertical co-ordination, stakeholder commitment, top management support and effective policy entrepreneurs. The framework draws on previous 
literature on gaining benefits from proactive ecological responses, such as the need for stakeholder integration and internal support from top management as well as effective managers. However, specific factors to reverse logistics are the quality of inputs and vertical co-ordination. A number of authors have stated that the quality of recycled material inputs needs to be high to compete with virgin material even if the cost is lower (den Hond 1996; Roy and Whelan 1992). Carter and Ellram propose that the greater the level of co-ordination between buyers and suppliers, the greater level of reverse logistics. Related to this is that where the input sector is uncertain, there will be a greater requirement for buyers to coordinate with suppliers, supported by Williamson's (1981) ideas of uncertainty leading to integration. Taking the explanation of reverse logistics further, Toffel (2002) argues that vertical integration in reverse logistics - what he calls end-of-life product recovery - can be explained using a transaction cost (TC) rationale. Using the behavioural assumptions of TC and the key concepts of asset specificity, uncertainty and transaction frequency, Toffel predicts how manufacturers will organise reverse logistics with respect to integration. The concept of asset specificity is used in two forms. The first is the specificity of the recovered component, where one OEM may value a recovered component more than other potential customers (i.e. because it can be re-used in new products). The second type is asset specificity in the recovery process where product-specific human resources or physical assets are used to gain cost efficiencies, but where these assets cannot be used for other products. Simply put, Toffel argues that where asset specificity, of both types is high, the recovery process will be integrated, and where it is low the process will be left to the market. However, combinations of these types of specificity may lead to alternative forms such as hybrids as defined by Williamson (1991).

The literature suggests that there are a number of factors that determine how end-of-life product recovery networks will be set up and how performance of these networks might be affected. Carter and Ellram (1998) provide an initial view on how factors may constrain reverse logistics, and yet given the importance of legislation in determining how firms respond to producer responsibility imperative, there is little evidence to date that shows how firms' responses are constrained by their institutional environments in this context.

\subsection{End of life product recovery capabilities}

Capabilities have been defined as the internal and external organisational skills, resources and functional competencies developed within firms to match the requirements of the external environment (Teece et al. 1997). Others have viewed capabilities as the things that shape what 
a firm can do in response (Barney 1991; Winter 1987). They have been described as being tacit, socially complex and rare (Dierickx and Cool 1989) or that they account for the diverging strategies in response to opportunities (Nelson and Winter 1982). More recent definitions of capability include "a high level routine (or collection of routines) that, together with its implementing input flows, confers upon an organization's management a set of decision options for producing significant outputs of a particular type” (Winter 2003: 991) or "a capacity to integrate, combine, and deploy tangible and intangible resources through distinctive organisational processes in order to achieve desirable objectives" (Lavie 2006a: 153).

Yet little is known about what happens if a firm does not possess the right set of capabilities for a given context, for example when the regulatory or competitive environment changes (Lavie 2006a). Firms may be able to develop or acquire capabilities and collaboration may have a role here (Hakansson and Snehota 1995; Jacobides and Winter 2005; McEvily and Marcus 2005). Thus given that firms often do not possess all the assets required for implementing end of life product recovery, it is necessary to identify which capabilities are needed and who within a network is in possession of them.

Since the development of legislative frameworks such as the end of life vehicle and waste electrical and electronic equipment directives (ELV and WEEE Directives), firms have been engaged in the process of identifying the required resources and associated capabilities to comply. Alongside this they have been deciding whether to integrate these activities and identifying potential firms with whom to develop relationships (contractual or otherwise) to meet these new legislative developments (as described in the previous section). Yet the acquisition or development of capabilities depends on both the competitive priorities of firms as well as the needs for legitimacy (i.e. compliance with regulations). Furthermore, the literature in general is lacking terms of descriptions of capabilities for product recovery. A few studies have described success factors for reverse logistics (Carter and Ellram 1998), while other have described typical activities such as disassembly, remanufacturing, refurbishment, product and process design, creating markets for waste products, dialogue with stakeholders ( Carter and Ellram 1998; Dowlatshahi 2000; Melnyk et al 2003; Rogers and Tibben-Lemke 2001; Thierry et al. 1995). Importantly, other research has started to integrate reverse logistics, remanufacturing and waste management into the mainstream of research into production optimisation (Richter and Dobos 1999; Tang and Grubbstrom 2005 as examples). Further, other studies have begun to consider the constraints of environmental 
legislation on production strategies (Dobos 2001). Yet a broader view on how the institutional environment affects production and supply chain strategies, and product recovery in particular, is needed.

\subsection{Institutional constraints}

The institutional perspective finds its roots in the observation that firms often show remarkable similarities that cannot be explained by industry type alone. As considered by DiMaggio and Powell (1991: 70), "The ubiquity of certain kinds of structural arrangements can more likely be credited to the universality of mimetic processes than to any concrete evidence that the adopted models enhance efficiency". Institutional theorists are able to show that the pressure to conform (to social norms) can result in inexplicable and inefficient organisational actions and structures, countering the efficiency arguments of traditional economic thought. As a basis for institutional theory, institutions are sets of rules accepted by broader society, which then take on a structure within organisations that determine the way firms should function (DiMaggio and Powell 1983; Zucker 1988).

Strategic responses are proposed to have links with these institutional processes. For example, motivational resistance to external pressures can be explained by way of institutional process factors such as the consistency of institutional norms with organisational goals or the amount of social legitimacy attained from a response (Pfeffer and Salancik 1978). Pressure to conform to these norms include coercive pressures (such as legislation), normative pressures such as professionalisation and mimetic pressures to reduce uncertainty (Martinez and Dacin 1999). Mimetic isomorphism whereby firms copy actions of other firms in the same industry occur to avoid taking risky actions or when the outcomes of certain actions are ambiguous (Bansal 2005; Martinez and Dacin 1999). For example, research has shown that mimetic isomorphism occurs within industry groups to both maintain legitimacy by imitating successful ecological strategies and to minimise the risk of being a first mover in a new market (Bansal and Roth 2000; Prakash 1999). Importantly, a major issue is that 'isomorphism' can be in conflict with competitive advantage gained from resources which are said to be idiosyncratic or heterogeneous (Barney 1991; Osborn and Hagedoorn 1997). Jennings and Zanderbergen's (1995) Institutionalist problem of isomorphism through compliance to the same legislation in the same way, potentially limits innovation, as less freedom is given to firms in their choice of response. While this explains why many firms are similar, especially in terms of structure, it also explains why advantage could be eroded through coercive, normative and mimetic pressures to conform to a single type (DiMaggio 
and Powell 1991). As aptly put by Selznick (1992: 232) “institutionalization constrains conduct in two main ways: by bringing it within a normative order, and by making it hostage to its own history".

Institutional theory (especially neo-institutionalist views) plays a large part in understanding why and how firms undertake product stewardship and a number of recent authors have used this perspective (Bansal and Clelland 2004; Jennings and Zanderbergen 1995; Prakash 1999). This perspective has been utilized in the field of supply chain management to a limited extent, for example recently explaining the 'bandwagon' of supply chain integration or the outsourcing of IT in firms (Frohlich and Westbrook 2002; Lacity and Hirschheim 1993). In addition to this, institutional effects have not been central to debates over collaborative relationships with Martinez and Dacin (1999) making specific mention of the impact of institutional fields on the ways firms build relationships.

A synopsis of these literature themes leads to the following aim for the study. It is recognised that there has been much research examining why and how firms adopt reverse logistics and product recovery, and specifically in the end-of-life product domain, this research has focused on identifying factors for success or the optimization of specific recovery processes such as remanufacturing inventory policies for example. Yet the overarching influence of institutional pressures has not been explicitly tackled by these studies. Hence this research aims to provide some guidance towards understanding the complexities of institutional influences on end-oflife product recovery actions by manufacturing firms and their network partners.

\section{Method}

The study is based on an in-depth investigation of the approaches to product recovery with a specific focus on the development of capabilities through supply chain relationships. Yet within the context of product recovery (a process subject to numerous legislative mandates and internal policy priorities), the role of context, and specifically the institutional environment, takes a central role in the analysis. Therefore the research design had to provide sufficient flexibility to provide meaningful findings in an area that is highly context dependent and under a considerable amount of change. Furthermore, the field can be viewed as relatively under-researched compared with other supply chain fields (Prahinski and Kocabasoglu 2006). As such, a case study approach was deemed appropriate (Stuart et al. 2002), as described in the following table 1.

INSERT TABLE 1 HERE 
A discussion of the unit and level of analysis provides further guidance towards an appropriate design for the research. It is proposed that the unit of analysis should both relate to the product at the industry level and the relationships between firms. This is because the product is the focal point of product stewardship activities such as recycling and reverse logistics. Furthermore, the relationship level allows the consideration of the implications of network effects, and capabilities developed at a relationship level. Further, to compare differences in recycling and reverse logistics activities it is convenient to compare across different product types as the influence of external and internal factors may be different. Figure 1 shows the scope of the case studies.

\section{INSERT FIGURE 1 HERE}

\subsection{Outline of the case characteristics}

The proposed level of analysis is both the firm and inter-firm activities and attributes such as information sharing, joint decision-making and shared planning activities, assets of firms, capabilities of firms, capabilities developed within firms and as a result of relationships. In order to facilitate this, the unit of analysis must be capable of capturing evidence from these levels.

There were a number of boundary setting criteria for the study. The first criteria is geographic, the UK. As collaboration is the phenomena under study, other variables relating to country differences can be accounted for by focusing on one country. Other antecedent conditions, such as the development of the industry, may also vary from country to country, so this was kept constant for the cases, where possible. The second boundary limit was those companies actually involved in the collection, take-back and recycling of end-of-life products as defined in the regulations (ELV and WEEE Directives), and specifically putting in place operations to meet these new regulations. A third boundary limit is the industry as defined by the products produced. Thus for each case only companies involved in producing and recycling a particular product type, such as a vehicle or photocopier, were used.

\subsection{The case study protocol}

This protocol was followed for each of the three cases (as well as a pilot case) to ensure a common approach to the data collection phase which is an important attribute of robust case study work (Ellram 1996; Stuart et al. 2002; Voss et al. 2002). A number of collaborative situations or dyads were sought within each case, to provide a degree of 'representativeness' 
(Yin 1981). Each dyad included a product manufacturer (who held responsibility for recovery, or would be implicated in new regulations) and a recycler (who actually carried out the actions of product take-back and recycling). Data collection followed a three stage process as should in figure 2 .

\section{INSERT FIGURE 2 HERE}

As figure 1 shows, the first stage was to map the network characteristics of the product recovery process of the OEM. This allowed a broad understanding of the specifics of the case and also the identification of key relationships with other partners, supporting the product recovery goals. The second stage of interviews was based on a semi-structured interview process including respondents from the cases and outside the cases, industry experts to provide an element of validation. Respondents were sought from a range of functional departments including logistics, operations, sales and marketing and environmental. In total 65 interviews were undertaken (a copy of the semi-structured interview schedule is available from the author). The third stage included site visits, observational data and documentation support where possible in order to improve the triangulation of data. The last stage involved the analysis of the cases. This was primarily driven through an iterative transcript analysis, coding data to support the identification of product recovery capabilities and institutional factors. The computer based analysis tool Nvivo was used for this purpose, mainly as a tool for handing the database of 65 interview transcripts and numerous other sources of evidence.

The overall case characteristics are displayed in Table 2.

\section{INSERT TABLE 2 HERE}

\section{Findings}

The study includes three case studies of product manufacturers who have developed relationships with product recovery specialists in order to meet organisational goals for product recovery, related to both internal policy commitments to reduce waste and also in response to current and potential future legislation. The three case studies can be described can be differentiated in terms of the specific product industries, both also in terms of the peculiarities of their product recovery systems which are briefly described next.

The tyre case study involves the development of a joint venture between a tyre manufacturer (Tyre Co) and a cement manufacturer (Tyre Partner 1), which resulted in the joint venture firm (Tyre Partner 2). Tyre Co had set up similar arrangements in other countries and foresaw that potential future producer responsibility legislation would lead to Tyre Co needing to 
implement a recovery process for its end-of-life products. Tyre Partner 1 was already using tyres in its cement process as a replacement fuel for coal, and had obtained the necessary permits. The main difficulty was obtaining a reliable flow of tyres from end users to the cement kilns. Hence the objective of the joint venture was to develop processes for providing a reliable supply of tyres to Tyre Partner 1, at sufficient volumes to show that Tyre Co was coordinating the environmentally friendly disposal of all its end of life tyres. In fact this objective was not met.

The copier case study involves the development of a specific recycling process by Copier Co with Copier Partner 1 (who is a recycling specialist operating in a number of sectors) for Copier Co's products, but also includes some of the activities that Copier Co carries out inhouse, including sorting and refurbishment of returned copiers. The case also includes activities that have been outsourced to a manufacturing specialist (Copier Partner 2) who has acquired some of the capabilities previously integrated by Copier Co. In particular, Copier Co has specific internal targets for reducing waste from returned products, in line with internal environmental policy targets and future legislative developments related to WEEE.

The automobile case encompasses the development of an end of life vehicle network in the UK based on the requirements of the ELV Directive. Auto Co developed relationships with both Auto Partner 1 and Auto Partner 2 as part of their requirement to demonstrate that they have a recycling network in place that meets the standards set out in recent regulations. The recovery process is based on providing the lowest cost solution for Auto Co, while providing no costs to the last users of vehicles. Therefore the Auto Partners $1 \& 2$ can feasibly pass on excess costs of handling and recycling vehicles to Auto Co, such as the cost of depolluting vehicles, and recovering certain parts and components and recycling the remaining waste product to agreed levels. In practice the organisations put in place processes to minimise these costs, and maximise revenues from parts sales so that the net cost of recovering vehicles is neutral to Auto Co. However, these processes are limited by the constraints of the legislation.

\subsection{Network design constraints}

The first stage of the research involved the mapping of product recovery networks for each of the main OEMs of the study (Copier Co, Auto Co and Tyre Co). These mapping sessions, involving personnel from a number functions (operations, environment department), were used to identify who was involved in the stages of product recovery, what their activities were, and in particular a focus the relationships between the OEM and other partners to gauge the level of capability access and development. This was examined by focussing on the 
collaborative elements of the relationships, such as information and knowledge sharing, involvement in $\mathrm{R} \& \mathrm{D}$, risk sharing, revenue sharing and the like.

\section{INSERT FIGURE 3 HERE}

The case studies exhibit a number of responses that are key to explaining why firms often do not follow purely economic efficiency arguments, which include direct pressure to conform and less direct pressure through mimetic isomorphism whereby firms copy actions of other firms in the same industry to avoid taking risky actions or when the outcomes of certain actions are ambiguous (Bansal 2005; Martinez and Dacin 1999). Hence the responses taken by the OEMs to contract or form joint ventures indicates that the relationships that are set up follow pre-defined frameworks of how product recovery 'should' be organised.

For examples, Tyre Co responded to potential producer responsibility regulations by setting up a JV because that is what Tyre Co had done in other countries. In the case of Auto Co the development of a common vehicle dismantler network for automotive recycling based on one prime contractor who would manage information flows to the other 'sub'contracting firms was based on the requirement of reaching certain recycling levels by the network overall as well as a legislatively defined network structure that fits certain geographical constraints on distance from last users of vehicles. From the perspective of Copier Co, the constraints on the network itself was much less. Therefore Copier Co was able to organise and develop relationships with recycling specialists as needed, within the constraints of its own Environmental Policy and related targets for recycling end of life products.

In summary then, the cases show that both the Tyre Co and Auto Co product recovery networks are constrained by institutionalised norms. In the case of Tyre Co it is a mimetic pressure to adopt a similar network structure to that developed elsewhere, even though a UK context may not be entirely compatible (due to public perception of tyre burning in cement kilns). Auto Co is subject to coercive pressure to both develop a network and how the network should operate. Whereas Copier Co is relatively more free to choose structural options that balance competitive and legitimacy priorities.

\subsection{Product recovery capabilities}

This research sought to identify the capabilities that support product recovery (and were perceived by practitioners to provide benefits in terms of the organisational goals). Hence the research led to thirteen distinct capabilities for product recovery, that are presented in the following table (Table 3). The capabilities included routines for influencing the institutional 
environment of the firms through marketing and influencing current and future legislation. They also included more technical aspects such a developing measures and technologies and controlling and coordinating the supply chain, related to new recycling processes and measures to ensure supply of end of life products or to reduce costs. Further, capabilities were also identified which linked to improving revenues such as customer-focussed programs, and processes that reduce compliance cost through shared spare part sales revenues.

\section{INSERT TABLE 3 HERE}

Furthermore, the description of capabilities was split between those that were pre-existing in the OEM or Partner company and those that were developed as a result of the relationship with the OEM. In all, the three cases' partners were chosen due there pre-existing capabilities for product recovery or potential to develop capabilities in line with the OEMs goals for product recovery.

Importantly for this research, not only were the capabilities identified, each of the capabilities at each of the nine companies was analysed in terms of heterogeneity (and therefore the ability to provide lasting competitive advantage to the OEM). The heterogeneity was defined at three levels. Low heterogeneity corresponded to resources and assets that could be transferred to other uses in other industries without significant losses. Medium heterogeneity corresponded to resources and assets that could only be used in a specific product industry (copiers, tyres or automobiles), but could be transferred to or utilised by other companies in that industry. High heterogeneity corresponded to those resources and assets that could only be used by the specific firm and its products, and transfer to other uses would lead to significant losses. Therefore each of the capabilities was assigned a level of low, medium or high. The cases exhibiting the low and medium levels of capability heterogeneity both centre round the tyre and automobile industry.

The case of Tyre Co who developed a joint venture with Tyre Partner 1 (who already had a solution for recovering tyres) and worked with Tyre Partner 2 (who developed capabilities for managing the return flow of tyres to Tyre Partner 1), revolves round the issue that Tyre Co had established similar systems in other countries in the past. The initial approach was to provide a similar process to the UK. However, Tyre Co soon found that the UK context provided some significant difficulties. First, the influence of Tyre Co over the distributors of tyres in the UK was lower than expected, and so Tyre Co could not guarantee that its tyres would be returned to Tyre Partners 1 and 2 as expected, and the system was open to any brand of tyre. Second, Tyre Partner 2's solution of burning tyres in cement kilns experienced 
significant public resistance, which it had not seen in other countries. Both these situations increased the amount of uncertainty in the supply and demand of tyres. Furthermore, as the process was open to all tyre brands, Tyre Co could not claim more specific benefits (e.g. reputational) than other tyre manufacturers.

The case of Auto Co, again exhibited low to medium levels of heterogeneity. In this sense the investments in assets and resources that supported a particular capability were transferable to all manufacturers of vehicles. While Auto Co has specific capabilities in design for product recovery, the actual recovery process itself was not designed to distinguish between one brand or another. In this sense any particular advantage in designing a more recyclable vehicle was lost in the application of a generic product recovery process that would not perform significantly differently between particular vehicle models. For example, the depollution equipment and skills to use this were generic for all makes and models. This is with the exception of one capability for 're-establishing the customer link' where Auto Co foresaw that a development with Auto Partner 1 could provide specific benefits if Auto Co was able to market a re-use program based on branded aftermarket parts, or an customer incentive for last users to use Auto Co's products (but these activities were only in the planning stage).

On the other hand, Copier Co was able to utilise existing capabilities and develop new capabilities with the partners in a manner that meant that resources and assets were specific to Copier Co and had the potential at least to provide competitive benefits such as lower costs for recovery and higher revenues from parts and material sales. The influence over legislation capability would have broad industry benefits, but the other capabilities relate to the way Copier Co can manage the demand of end-of-life products through controlled retirement and the way that forward and reverse logistics flow are integrated to provide high levels of control and reduce costs. The development of recovery processes with partners, especially Copier Partner 1 who shared a common site, was particularly beneficial as it was the only example in the study of a truly closed loop recycling system for copier plastic, used by Copier Co in new and refurbished machines.

In the product recovery processes studied here where the main driver is legitimacy (the need to comply with social norms such as legislation), firms that choose to respond by contracting with other firms marketed as a 'compliance solution' will find it difficult to achieve heterogeneity in their response, even if collaboration with partners leads to specific exchanges. The research shows that contracting to gain access to capabilities, that are based on industry level investments, limits the responses firms can make. Hence, the universal 
approach to the product recovery is likely to lead to isomorphic responses, a phenomena grounded in institutional theory.

The influence of institutional forces are evident across the case studies, in particular the influence of coercive and mimetic pressures. This research shows examples of these two pressures, for example that the level of information sharing can be legislated thus mandating flows between firms (for example demand, supply, performance such as recycling levels and design information). Also collaborative relationships (the Tyre Co and Tyre Partner 1 joint venture is a case in point) can have an historical precedent in the originator firm, or where the view of the 'industry' through the trade associations and working groups is to work collaboratively (a normative prescription). Therefore capabilities identified in both the Tyre Co and Auto Co cases could be viewed as driven from institutional processes reacting to the ambiguity of efficiency arguments as well as the direct coercive effects of legislators.

\section{Conclusions}

This research offers three main conclusions that are considered significant for both theory and practice within the domain of end-of-life product recovery. First is the identification of important capabilities for product recovery within an institutional context. These capabilities can be further categorised into 'process specific' and 'managing institutional environments', but these are interdependent. For example the ability to influence legislation presupposes that a firm has legitimate processes in place to convince legislators of possible alternatives to policy.

Specifically, coercive pressure, notably legislation (but also codes of conduct and voluntary agreements) constrain the type of processes put in place, and importantly their competitive value (as indicated by capability heterogeneity in table 3 ). Hence, where coercive pressure forces firms at an industry level to adopt a specific process and network structure, the ability to forge individual approaches, and therefore competitive advantage, is limited. Normative pressure such as those presented by industry groups e.g. trade associations also influence the processes adopted. Again this tends to reinforce an industry level approach as opposed to individualistic (e.g. the automotive sector case study). As one automotive OEM manager stated “I don't think anybody's got much of a competitive strategy", or another "within the UK car manufacturers we've treated end of life vehicle and issues of how recyclable is your car as a non-competitive issue..”. 
In the face of uncertainty, mimetic behaviour tends to play a greater role in determining choices of product recovery process. In the tyre case this was manifest in the duplication of the approach in other countries. Yet without considering the specifics of a different country context, this may not be optimal as Tyre Co found, both in relation to its influence of the supply chain but also in the perceived legitimacy of their approach by the general public.

The approach to research to date on end-of-life product recovery has been based on identifying the optimum solution for minimising costs or maximising revenue. Yet these cases show that there are multiple objectives which additionally encompass reputation improvement (or even maintenance) and the broader issue of legitimacy, a central concept to institutional thinking. This complicates the decisions over best approaches to product recovery as there are high levels of uncertainty in its multiple forms, and hence institutional forces display a strong influence over the selected direction of firms.

One could argue that product recovery is becoming more strategic as legislation further challenges firms' licence to operate. This development may encourage a re-think of the business models employed where product recovery could be more integrated into the mainstream business, such as at Copier Co. For this to happen, market incentives need to be in place for example a shift to product-service systems (something the EU already considers) perhaps instead of the coercive, choice limiting approaches, currently adopted by legislators.

Considering this research in the broader context of the development of the field, highlights some areas for future research. The results of this study would suggest a broader remit for research within production and operations management, to consider the effects of institutional forces on the development of capabilities and choice of production strategy (both in forward and reverse supply chains). Not only do these forces constrain choices, they also constrain the possible value obtained from these choices. Hence, further research would be particularly helpful in the area of organisational choice models, where multiple conflicting criteria are to be considered, such as AHP approaches. A further difficulty is the inclusion of more intangible dimensions such as reputation and legitimacy into current models of optimisation. While this research does not provide a solution, researchers in the field should be challenged to find a way to incorporate these elements, which are clearly important in the selection of possible alternatives. 


\section{Bibliography}

Bansal, P. 2005, 'Evolving Sustainably: A Longitudinal Study of Corporate Sustainable Development', Strategic Management Journal, Vol. 26, No. 3, 197-218.

Carter, C.R. and Ellram, L.M. 1998, 'Reverse logistics: a review of the literature and framework for future investigation', Journal of Business Logistics, Vol. 19, No. 1, 85-102.

den Hond, F 1996, 'In search of a useful theory of environmental strategy: A case study of the recycling of end-of-life vehicles from a capabilities perspective', $\mathrm{PhD}$ (Vrije Universiteit).

Dewhurst, P. 1993, 'Product design for manufacture: design for disassembly', Industrial Engineering, Vol. 25, No. 9, 26-28.

DiMaggio, P and Powell, W.W. 1983, 'The iron cage revisited: Institutional isomorphism and collective rationality in organisational fields', American Sociological Review, Vol. 48, No. April, 147-60.

DiMaggio, P and Powell, W.W. 1991, The New Institutionalism in Organizational Analysis (Chicago: The University of Chicago Press).

Dobos, I. 2001 Production stratgies under environmental constraints: Continuous-time model with concave costs, International Journal of Production Economics, 71, 323-30

Dowlatshahi, S 2000, 'Developing a theory of reverse logistics', Interfaces, 30, 3, 143-55.

Fleischmann, M, Krikke, H.R, Dekker, R, and Flapper, S.D.P. 2000, 'A characterisation of logistics networks for product recovery', Omega, 28,. 6, 653-66.

Frohlich, M and Westbrook, R 2002, 'Demand chain management in manufacturing and services: webbased integration, drivers and performance', Journal of Operations Management, Vol. 20, No. $6, .729-45$.

Guide Jr, D.R and Wassenhove, L. N Van (eds.) 2003, Business Aspects of Closed-loop supply chains (International Management Series, Pittsburgh, Pennsylvania: Carnegie Mellon University Press).

Guide Jr, D.R and Wassenhove, L. N Van 2002, 'The Reverse Supply Chain', Harvard Business Review, Vol. 80, No. 2, 25-26.

Hakansson, H and Snehota, I 1995, Developing relationships in business networks (London: Routledge).

Jacobides, M.G and Winter, S.G. 2005, 'The Co-Evolution of Capabilities and Transaction Costs: Explaining the Institutional Structure of Production', Strategic Management Journal, Vol. 26, No. 5, 395-413.

Jennings, P.D. and Zanderbergen, P.A. 1995, 'Ecologically sustainable organisations: an institutional approach', Academy of Management Review, Vol. 20, No. 4, 1015-52.

Knemeyer, A.M, Ponzurick, T.G, and Logar, C.M [2002], 'A qualitative examination of factors affecting reverse logistics systems for end-of-life computers', International Journal of Physical Distribution and Logistics Management, 32, . 6, 455-79.

Lacity, M and Hirschheim, R 1993, 'The information systems outsourcing bandwagon', Sloan Management Review, Fall,. 73-86.

Lavie, D 2006a, 'Capability reconfiguration: An analysis of incumbent responses to technological change', Academy of Management Review, 31, 1, 153-74.

Martinez, R.J. and Dacin, M.T. 1999, 'Efficiency motive and normative forces: combining transaction costs and institutional logic', Journal of Management, Vol. 25, No. 1, 75-103.

Mayers, K and France, C 1999, 'Meeting the 'producer responsibility' challenge', Greener Management International, Vol. 25, 51-66.

McIntyre, K, Smith, H.A., Henham, A, and Pretlove, J 1998, 'Logistics performance measurement and greening supply chains: diverging mindsets', The International Journal of Logistics Management, 9, 1, 57-59.

Melnyk, S.A., Sroufe, R, P, and Calantone, R 2003, 'Assessing the impact of environmental management systems on corporate and environmental performance', Journal of Operations Management, 21, 3, 329-51.

Nelson, R.R. and Winter, S.G. 1982, An Evolutionary Theory of Economic Change (Cambridge, Massachusetts: Harvard University Press). 
Oliver, C. 1991, 'Strategic responses to institutional processes', Academy of Management Review, 16, 1,145 .

Pfeffer, J and Salancik, G.R. 1978, The External Control of Organization (New York: Harper and Row).

Pohlen, T.L and Farris, M.T 1992, 'Reverse logistics in plastics recycling', International Journal of Physical Distribution and Logistics Management, 22, 7, 35-47.

Prahinski, C and Kocabasoglu, C. 2006, 'Empirical research opportunities in reverse supply chains', Omega,34, 519-32.

Prakash, A 1999, 'A New-institutionalist Perspective on ISO14001 and Responsible Care', Business Strategy and the Environment, 8, 322-35.

Richter, K. and Dobos, I. 1999, Analysis of the EOQ repair and waste disposal problem with integer setup numbers, International Journal of Production Economics, 59, 463-467.

Rogers, D.S and Tibben-Lemke, R 2001, 'An examination of reverse logistics practices', Journal of Business Logistics, 22, 2, 129-48.

Roy, R and Whelan, R 1992, 'Successful recycling through value chain collaboration', Long Range Planning, 25, . 4, 62-71.

Seitz, M and Peattie, K 2004, 'Meeting the closed loop challenge: The case of remanufacturing', California Management Review, 46, . 2, 74-89.

Selznick, P 1992, The Moral Commonwealth: Social Theory and the promise of Community (Berkeley: University of California Press).

Sharfman, M., Ellington, R.T., and Meo, M. 1997, 'The next step in becoming "green": life-cycle oriented environmental management', Business Horizons, 40, (3), 10-13.

Spicer, A.J and Johnson, M.R 2004, 'Third-party demanufacturing as a solution for extended producer responsibility', Journal of Cleaner Production, 12, 37-45.

Tang, O., and Grubbstrom, R.W. 2005, Considering stochastic lead times in a manufacturing / remanufacturing system with deterministic demands and returns, International Journal of Production Economics, 93-94, 285-300.

Teece, D. 1987, 'Profiting from technological innovation: Implications for integration, collaboration, licensing and public policy', in D. Teece (ed.), The Competitive Challenge (Cambridge, MA: Ballinger), 185-220.

Thierry, M., Salomon, M., Van Nunen, J., and Wassenhove, L van. 1995, 'Strategic issues in product recovery management', California Management Review, Vol. 37, No. 2, pp. 114-36.

Toffel, M 2003, 'The Growing Strategic Importance of End-of-Life Product Management', California Management Review, 45, 3, 102-29.

Walley, N and Whitehead, B 1994, 'It's not easy being green', Harvard Business Review, Vol. MayJune, 46-51.

Walther, G and Spengler, T 2005, 'Impact of WEEE-directive on reverse logisics in Germany', International Journal of Physical Distribution \& Logistics Management, 35, 5, 337-61.

Whiston, T.G 1995, 'Disposal and Recycling of Motor Vehicles: An International Perspective', (Final version of a study commissioned by the Commission of the European Union DGXII: Brighton, Sussex: SPRU).

White, C.D., Masanet, E., Rosen, C.M., and Beckman, S.L. 2003, 'Product recovery with some byte: an overview of management challenges and environmental consequences in reverse manufacturing for the computer industry', Journal of Cleaner Production, 11, 445-58.

Williamson, O.E. 1981, 'The economics of organization: The transaction cost approach', American Journal of Sociology, . 87, 548-77.

Winter, S 2003, 'Understanding Dynamic Capabilities', Strategic Management Journal, 24, 991-95.

Zucker, L.G. (ed.), 1988, Institutional patterns and organisations (Cambridge, Massachusetts: Ballinger Publishing Company). 


\section{Table 1}

\section{Outline of the research design}

\begin{tabular}{|c|c|c|}
\hline $\begin{array}{l}\text { Aspect of } \\
\text { design }\end{array}$ & Description & Rationale \\
\hline Type of research & Empirical case study & $\begin{array}{l}\text { Most of the research relating to reverse logistics as focused } \\
\text { on conceptual analysis and development, thus cases, as } \\
\text { stated by Wacker } 1998 \text { "Tests and develops complex } \\
\text { relationships between variables to suggest new theory" }\end{array}$ \\
\hline $\begin{array}{l}\text { Refutation } \\
\text { method }\end{array}$ & $\begin{array}{l}\text { Induction and analysis of } \\
\text { logical inconsistency }\end{array}$ & $\begin{array}{l}\text { A conceptual framework has been developed, but the } \\
\text { linkages between concepts need to be defined through an } \\
\text { inductive approach from the data }\end{array}$ \\
\hline Level of analysis & The firm and the relationship & To understand outcomes at a firm and relationship level \\
\hline Unit of analysis & $\begin{array}{l}\text { The product and the } \\
\text { relationship }\end{array}$ & $\begin{array}{l}\text { To compare across product industry types and across } \\
\text { industry types }\end{array}$ \\
\hline Number of cases & Three & To compare across different products and firms \\
\hline Type of cases & Nested cases of dyads & $\begin{array}{l}\text { To compare different firms, relationships between firms } \\
\text { and control for product industry by including more than } \\
\text { one dyad per product }\end{array}$ \\
\hline
\end{tabular}

Figure 1

The scope of the research study

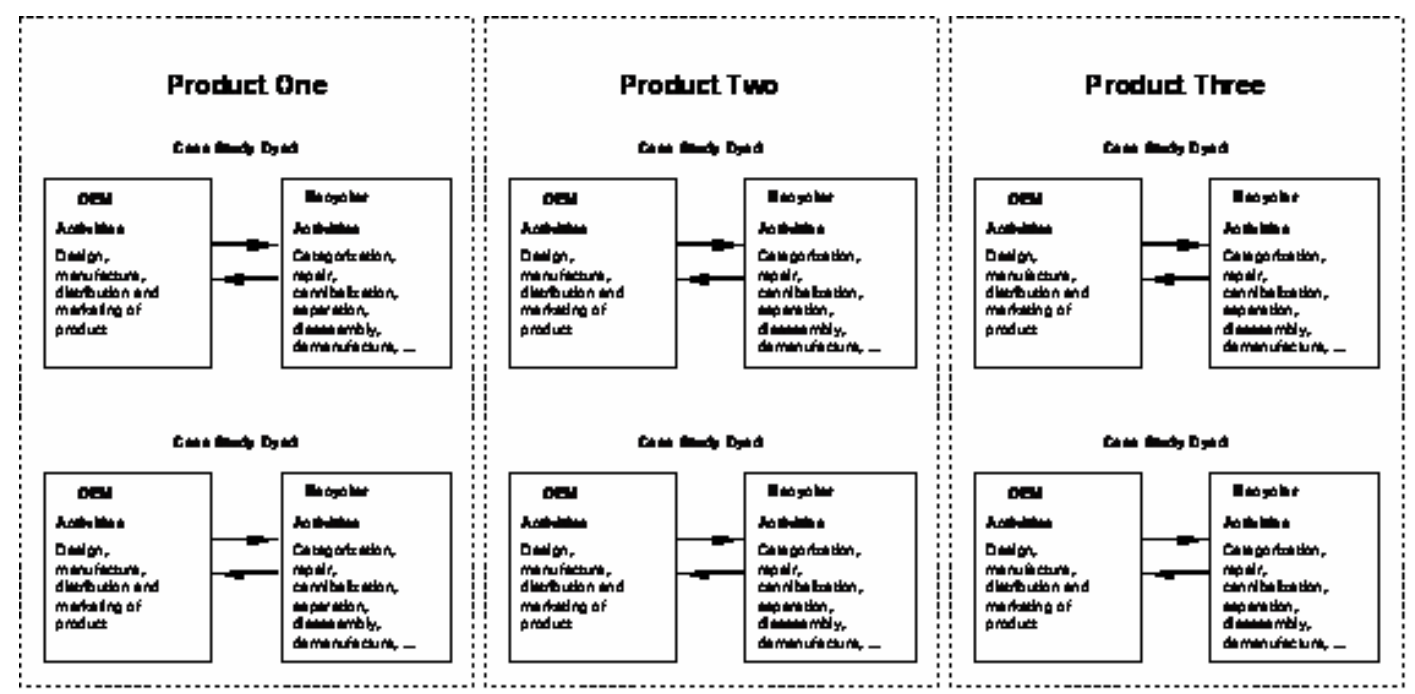

Figure 2

The research protocol process followed in the research 


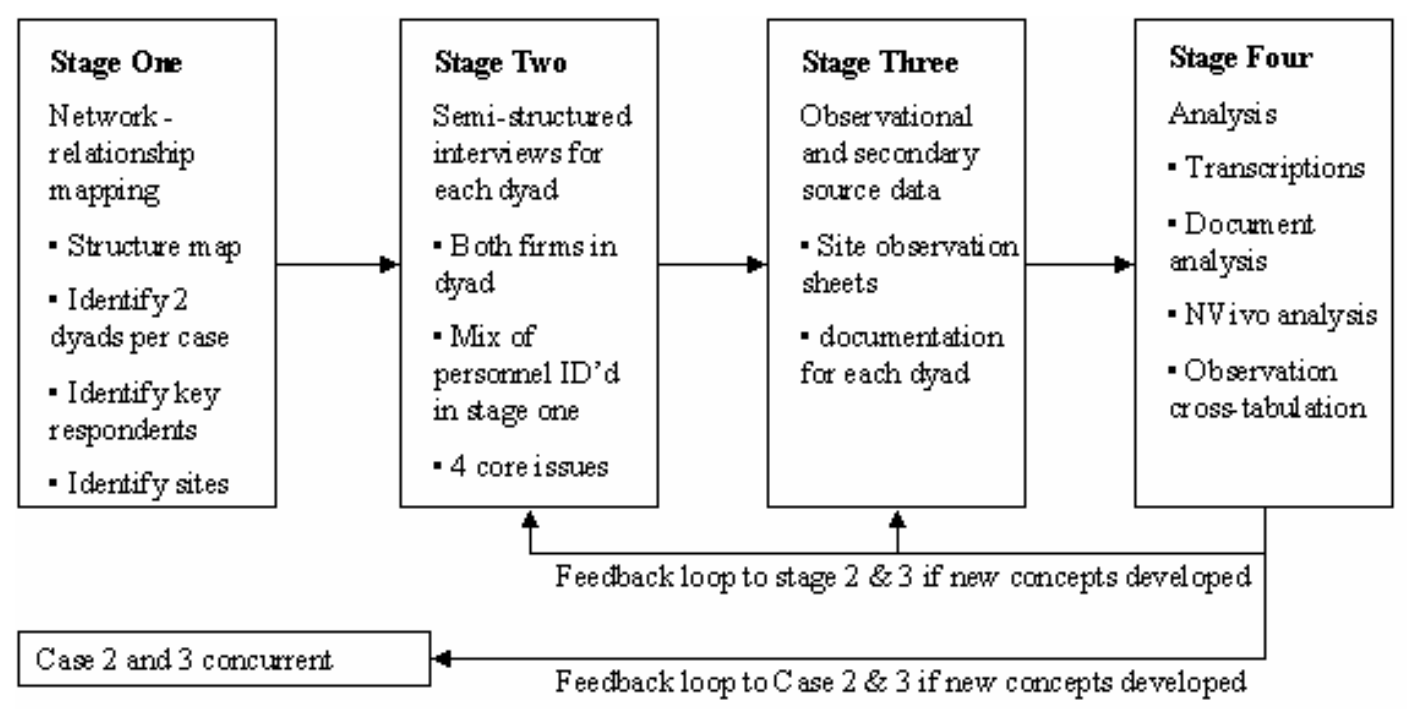

Table 2

Case characteristics

\begin{tabular}{llll}
\hline Characterstic & Tyre Case & Copier Case & Auto Case \\
\hline OEM & Tyre Co & Copier Co & Auto Co \\
\hline Partners & Tyre Partner 1 & Copier Partner 1 & Auto Partner 1 \\
& Tyre Partner 2 & Copier Partner 2 & Auto Partner 2 \\
\hline Product & Tyres & Photocopiers & Automobiles \\
\hline Volumes & c. $10,000,000$ & 39,000 & 300,000 \\
\hline No. parts / materials & 200 & c.1000 & c.3000 \\
\hline
\end{tabular}

Figure 3

A generic network map of product recovery centred round a single OEM 


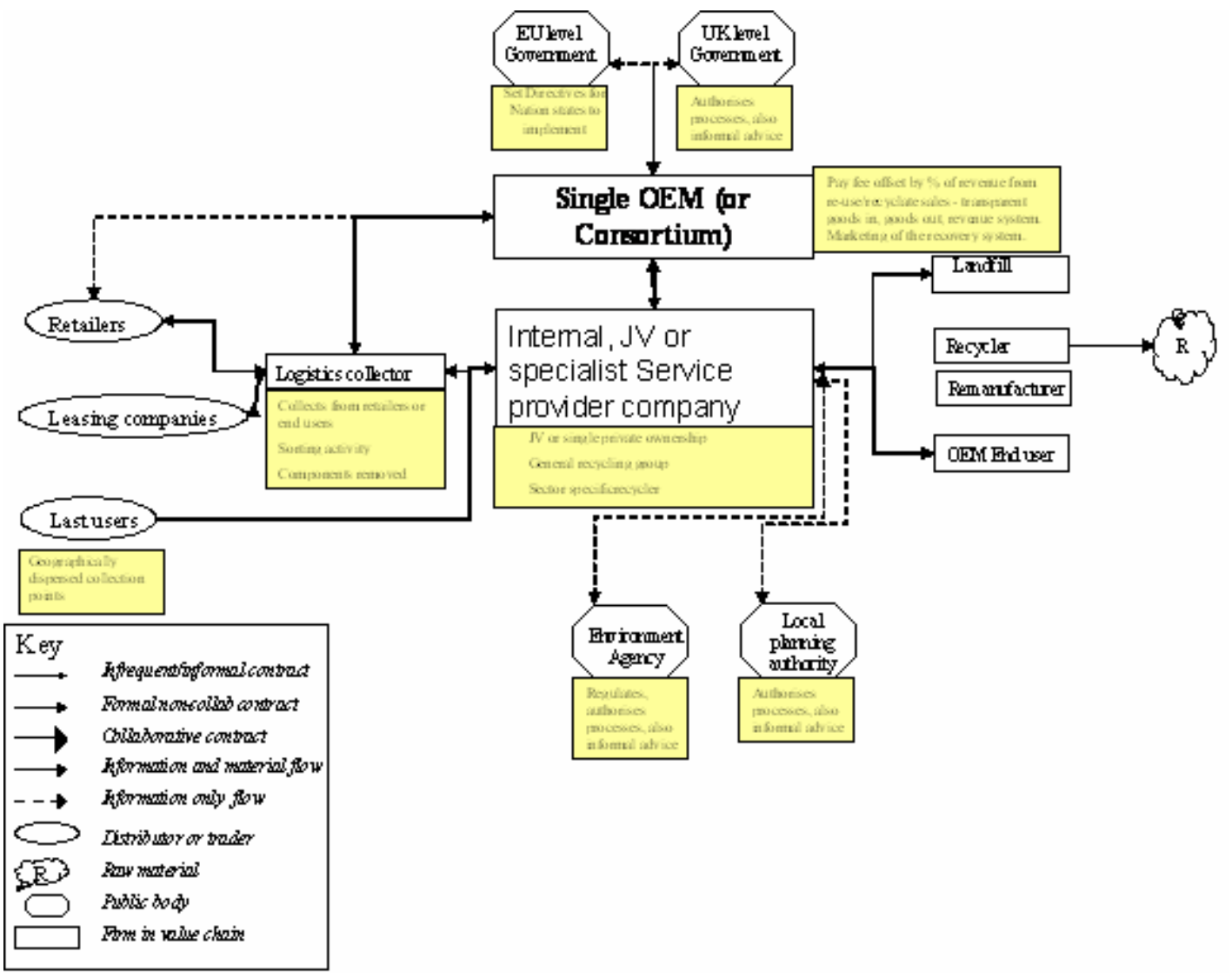

Table 3

The identified capabilities for product recovery 


\begin{tabular}{|c|c|c|}
\hline Firm & Capability type & Heterogeneity \\
\hline Tyre Co & $\begin{array}{l}\text { Pre-existing } \\
\text { - Marketing } \\
\text { - Use position in the supplier chain } \\
\text { - Network to find expertise }\end{array}$ & $\begin{array}{l}\text { Low } \\
\text { Med } \\
\text { Med }\end{array}$ \\
\hline $\begin{array}{l}\text { Tyre } \\
\text { Partner } 1\end{array}$ & $\begin{array}{l}\text { Pre-existing } \\
\text { - Develop measures and technologies to support product recovery }\end{array}$ & Med \\
\hline $\begin{array}{l}\text { Tyre } \\
\text { partner } 2\end{array}$ & $\begin{array}{l}\text { Developed } \\
\text { - Develop measures and technologies to support product recovery } \\
\text { - Control and coordinate the supply chain }\end{array}$ & $\begin{array}{l}\text { Med } \\
\text { Med }\end{array}$ \\
\hline Copier Co & $\begin{array}{l}\text { Pre-existing } \\
\text { - Influence design for product recovery } \\
\text { - influence legislation } \\
\text { - Use position in the supply chain } \\
\text { - Develop measures and technologies to support product recovery } \\
\text { - Control and coordinate the supply chain } \\
\text { - Build up processes over time } \\
\text { - Create a customer focused program }\end{array}$ & $\begin{array}{l}\text { High } \\
\text { Med } \\
\text { High } \\
\text { High } \\
\text { High } \\
\text { High } \\
\text { High }\end{array}$ \\
\hline $\begin{array}{l}\text { Copier } \\
\text { partner } 1\end{array}$ & $\begin{array}{l}\text { Pre-existing } \\
\text { - Control and coordinate the supply chain } \\
\text { - Introduce measures and technologies for product recovery } \\
\text { - Create a customer focused program } \\
\text { - Provide revenue to reduce compliance costs } \\
\text { Developed } \\
\text { - Introduce measures and technologies for product recovery } \\
\text { - Use position in the supplier chain }\end{array}$ & $\begin{array}{l}\text { Med } \\
\text { High } \\
\text { High } \\
\text { Med } \\
\text { High } \\
\text { Med }\end{array}$ \\
\hline $\begin{array}{l}\text { Copier } \\
\text { Partner } 2\end{array}$ & $\begin{array}{l}\text { Developed (ACQUIRED) } \\
\text { - Control and coordinate the supply chain } \\
\text { - Influence design for product recovery } \\
\text { - Build up processes over time } \\
\text { - Introduce measures and technologies for product recovery } \\
\text { - Create a customer focused program }\end{array}$ & $\begin{array}{l}\text { High } \\
\text { High } \\
\text { High } \\
\text { High } \\
\text { HIgh }\end{array}$ \\
\hline Auto Co & $\begin{array}{l}\text { Pre-existing } \\
\text { - Influence design for product recovery } \\
\text { - Marketing } \\
\text { - Influence future legislation } \\
\text { Developed } \\
\text { - Influence future legislation } \\
\text { - Re-establish customer link }\end{array}$ & $\begin{array}{l}\text { High } \\
\text { High } \\
\text { Med } \\
\text { Low } \\
\text { High }\end{array}$ \\
\hline $\begin{array}{l}\text { Auto } \\
\text { Partner } 1\end{array}$ & $\begin{array}{l}\text { Pre-existing } \\
\text { - Provide revenue to reduce compliance costs } \\
\text { - Introduce measures and technologies for product recovery } \\
\text { - Build up processes over time } \\
\text { - Network linkages for recovery } \\
\text { Developed } \\
\text { - Influence future legislation } \\
\text { - Provide revenue to reduce compliance costs } \\
\text { - Build legitimacy } \\
\text { - Marketing }\end{array}$ & $\begin{array}{l}\text { Med } \\
\text { Med } \\
\text { Med } \\
\text { Med } \\
\text { Low } \\
\text { Med } \\
\text { Med } \\
\text { Med }\end{array}$ \\
\hline $\begin{array}{l}\text { Auto } \\
\text { Partner } 2\end{array}$ & $\begin{array}{l}\text { Pre-existing } \\
\text { - Provide revenue to reduce compliance costs } \\
\text { - Introduce measures and technologies for product recovery }\end{array}$ & $\begin{array}{l}\text { Med } \\
\text { Med }\end{array}$ \\
\hline
\end{tabular}

